\title{
Alienation and Militancy in the Niger Delta: Hostage Taking and the Dilemma of the Nigerian State
}

\author{
Ibaba S. Ibaba *
}

\section{Abstract}

This paper examines the linkages between alienation and militancy in Nigeria's Niger Delta region, and the dilemma the Nigerian State faces in dealing with the menace of hostage taking of oil workers in the region by militant groups. To achieve this objective, the paper critically discusses the centrality of alienation in the seemingly intractable youth violence in the Niger Delta. It demonstrates that alienation, caused by ethnicity based political domination, oil based environmental degradation, corruption and parental neglect has engendered frustration and awareness that explain the conflicts and violence in the area. The paper points out that protests and agitations that were hitherto peaceful degenerated to militancy, violence and hostage taking, due to violent state repression and the militarisation of the Niger Delta. Hostage taking of oil workers, particularly expatriates, now occurs frequently in the Niger Delta, with destructive effects on the country's economy, due to disruptions in oil production. The paper blames this on the character of the State and the resultant dilemma it faces. The Nigerian State is privatised and is

* Dr Ibaba is Lecturer 1 in the Department of Political Science, Niger Delta University, Wilberforce Island, Bayelsa State, Nigeria. 


\section{Ibaba S. Ibaba}

therefore used to pursue personal, sectional and ethnic interests, as against the common interests. The inability of the state to choose the pursuance of the public good has undermined its ability to deal with militancy and hostage taking. It has laid the foundations of militancy through a neglect of development, and promotion of political thuggery in the electoral process. The solution hinges on the transformation of the state; to make it address the aspirations of citizens.

\section{Introduction}

The Niger Delta is one of the world's largest wetlands, and Africa's largest delta, covering some $70000 \mathrm{~km}^{2}$ (World Bank 1995:1). It lies within the Ibo Plateau and the Cross River Valley (Willinks Commission Report 1957:9). The dominant view sees the constituent states of the region as Akwa-Ibom, Bayelsa, Cross River, Delta, Edo and Rivers (Tamuno 2000:12).

The Niger Delta is evidently blessed with numerous resources, including crude oil that accounts for about 80 percent of Nigeria's foreign exchange earnings. Despite its immense oil wealth, the region presents an example of extreme poverty, as vast oil revenues have barely touched pervasive local poverty (United Nations Development Programme 2006:9). This condition has incensed the people, leading to protests that have taken different forms. Owugah (1999:5-8) has categorised these agitations into four phases. According to him:

The first phase could be roughly put between the early and mid 1980's. The dominant strategy in this phase was that of legal action by the communities against the oil companies to pay adequate compensations for damages to their property... The second phase was characterized by peaceful demonstrations and occupation of flow stations to get the oil companies to pay 'adequate' compensations or to fulfill their promises to provide certain amenities and to employ indigenes of the community... the oil companies responded by calling in the police and military. The intervention of these state 
operatives often resulted in destruction of lives and property... The resistance thus assumed a desperately militant form in the third phase...mid 1990's to 1998... characterized by the militant strategy of forceful occupation and shutting down of flow stations, kidnapping of workers, seizure of tug boats and other vessels belonging to the oil companies... The fourth phase is the demand for resource ownership and control.

Two crucial issues are discernible from the above reference. Firstly, that feelings of alienation are a fundamental cause of conflict in the Niger Delta. Secondly, the deepening of the conflicts and the resultant hostage taking are a result of government's insensitivity to these feelings, demonstrated by its violent response to community agitations or popular protests.

As stated above, the demand for resource ownership and control marks the fourth phase of the Niger Delta people's struggle for integration into the oil wealth. In this regard, the Ogoni Bill of Rights (1990), the Kaiama Declaration (1998), the Bill of Rights of the Oron People (1999), the Resolutions of the First Urhobo Economic Summit (1998), the Aklaka Declaration (1999) and the Warri Accord (1999) made resource ownership and control their cardinal objectives. For example, the 1990 Ogoni Bill of Rights stated in part that:

The Ogoni people be granted political autonomy... provided that this autonomy guarantees... the right to the control and use of a fair proportion of Ogoni economic resources for Ogoni development...

The Kaiama Declaration of 1998 was more emphatic. It declared that:

All land and natural resources (including mineral resources) within the Ijaw territory belong to Ijaw communities and are the basis of our survival. We cease to recognize all undemocratic Decrees that rob our people/communities of the right to ownership and control of our lives. 


\section{Ibaba S. Ibaba}

Government's response to these campaigns was repression. For example, Ogoni land was under siege for years, and Kaiama was invaded by federal troops. To resist the military might of the State; armed confrontation was adopted by the youths as a defence mechanism (Joab-Peterside 2005:48). As part of this confrontation and protest against the multinational oil companies, kidnapping of oil company personnel, particularly expatriate staff, became a useful tool, as it restrains security operatives and brings in substantial money to the captors.

Hostage taking by Niger Delta militants was a worrisome dimension in 2006 due to the frequency and intensity of such events. Between January and December 2006, a total of 24 incidents, involving 118 hostages, have been recorded (AfricaMasterWeb 2006). Despite the deployment of federal troops in the region, and the presidential shoot-at-sight order, the militants remain undaunted and continue to hold sway.

But why is it difficult for the Nigerian State to effectively tackle these militants? The objective of this paper is to answer this question. It argues that the inability of the State to deal with the issue of militancy and hostage taking is attributable to its privatisation and the resultant two-way dilemma. Firstly, the State has taken sides in the Niger Delta crisis, and therefore cannot mediate. Secondly, the nature of the State undermines the fight against corruption. Due to corruption, which in addition to stealing government monies manifests as election rigging, development has been neglected, and many citizens hold the State in contempt.

The remaining part of the paper is organised into 3 sections. The first section examines the linkages between alienation and militancy in the Niger Delta. Section two deals with the dilemma of the Nigerian State in relation to hostage taking in the Niger Delta. The third section concludes. 


\section{Alienation and Militancy in the Niger Delta}

It is not in doubt that alienation is the root cause of militancy in the Niger Delta (Joab-Peterside 2005:30-51). To this end, alienation from natural resources, means of livelihood and species being endangered have been noted (Frederick 2008:5). The literature on the Niger Delta agrees that the oil industry has not promoted the development of the region; rather, it has undermined the area's development (Ikein 1991; Brown 1998; Enyia 1991; Okoko \& Nna 1997; Aaron 2006a). For example, Aaron (2006a:194) has noted that:

Oil has meant for the indigenes of the Niger Delta, wrenching poverty...Peoples Rights have come under severe assault by the ecologically unfriendly practices of oil Transnational Corporations (TNC's). In addition, State laws and policies as they relate to petroleum resources, expropriate the indigenous peoples of the Niger Delta of their 'right' to their natural resources ... According to Brown [1998], the local economies of the Oil Producing Communities have collapsed. And they are not integrated into the oil economy of Nigeria...the success of the oil economy has not promoted their own capacities. It has not promoted their own self-reliance. It has not promoted the social engine of the society... the pace of development has left them.

The point is that oil based environmental degradation and ethnic based political domination have combined to alienate the people from the use of their natural resources for their own development. Oil exploration and production is associated with a number of activities that devastate the environment, and impact negatively on economy and society. Several sources (Okoko 1998; Ikporukpo 1983; Aaron 2006a; Ikein 1991; Worika 2002; Salau 1993; World Bank 1995; Ibaba 2005; United Nations Development Programme (UNDP) 2006; Adeyemo 2002; Human Rights Watch (HRW) 1999; Ibeanu 1997; Niger Delta Environmental Survey 1997; Peel 2005; Clark et al 1999; African Network for Environment and 


\section{Ibaba S. Ibaba}

Economic Justice (ANEEJ) 2004; Naanen 1995; Opukri \& Ibaba 2007) have demonstrated the impact of the oil industry on the economy and society of the Niger Delta.

Oil spills kill fish and agricultural crops, in addition to reducing nutrient value of the soil (HRW 1999:5-12; Clark et al 1999). Studies have shown that gas flares diminish agricultural productivity. It has been noted that crops planted about 200 metres from flare sites lose 100 percent of their yield. Those planted about 600 metres from flare sites experience 45 percent loss in yield, and 10 percent loss in yield for crops planted one kilometer away from gas flares (Salau 1993:19-22; Adeyemo 2002:69).

But what are the impacts of this on the Niger Delta people? The results are productivity losses, occupation displacement/disorientation, and increased poverty (UNDP 2006:175-311; World Bank 1995:8-66). Development has stagnated, and no matter how hard peasants work, they remain at the same point, and sometimes their situation gets worse. This has caused frustration and, as psychologists have noted, conflicts are a response to the frustration which occurs as a result of obstacles against the actualisation of set goals (Anikpo 1998:7). The frustrationaggression theory of conflict also supports this perspective (Faleti nd:47). Certainly, this theory captures the Niger Delta condition where frustration has led to youth militancy and violence.

Alienation caused by the environmental consequence of the oil industry has been exacerbated by ethnic based political domination and the failures of accountability and transparency in government. Naanen (1995), Okoko and Nna (1997), Joab-Peterside (2005) and Orobator et al (2005) see the ethnicised Nigerian State and its disabled federal system as fundamental causes of the development impotence in the Niger Delta.

Because the State is ethnicised, power is used to promote sectional interests as against the common interests. The State in Nigeria is controlled by members of the dominant ethnic groups, who direct oil resources produced in the ethnic minority homelands of the Niger Delta to their 


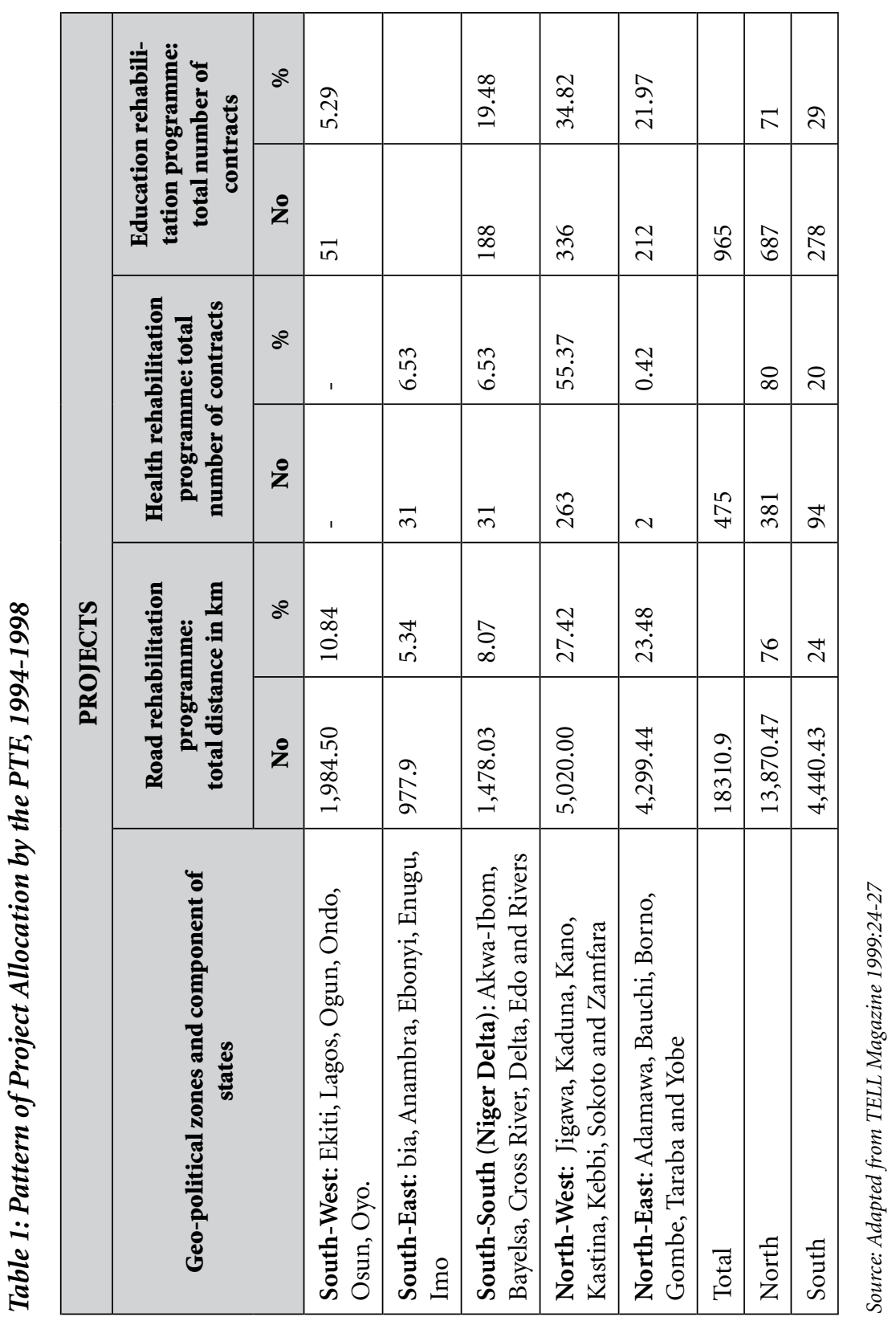




\section{Ibaba S. Ibaba}

benefit. This is evidenced by the manipulations of the revenue allocation mechanism to satisfy their interests.

At independence, sections 134(1) and 140(1) of the 1960 and 1963 constitutions provided for a derivation principle of 50 percent (Constitution of the Federal Republic of Nigeria 1960, 1963). Because agriculture was the mainstay of the Nigerian economy, this provision was adhered to, since it favoured the ethnic majorities whose homelands were host to the cash crops of cocoa, groundnut, and palm oil that generated the dominant share of national revenues. But as oil displaced agriculture as the productive base of the economy, the derivation principle was whittled down from 50 percent to 45 percent in 1975, and later to 1.5 percent in 1982.

The weakening of the derivation principle, and the adoption and strengthening of other criteria - such as land mass, equality of States, need and population - ensured the transfer of the oil wealth out of the Niger Delta. These principles provided more funds for the regions that were balkanised into more States and local governments, and thus became instruments of wealth distribution from the Niger Delta to other sections of the country (Mbanefoh \& Egwaikhide 1998:220; Okorede 1998:28).

The politics of revenue allocation has denied the Niger Delta adequate development funds. Of significance is the fact that development agencies of the Nigerian State are guilty of alienating the Niger Delta. The Petroleum Trust Fund (PTF) is a classic example. See table 1 (on page 17).

The information in table 1 shows that out of a total of 18,310.9 kilometres of road rehabilitated by the PTF, the Northern States received 13,870.47 (76 percent) while the Southern States got 4,440.43 (24 percent). Significantly, the Niger Delta States, which bear the burden of generating the oil wealth, received 1,479.03 kilometres (8.07 percent). Similarly, out of a total contract package of 475 for the PTF National Health Rehabilitation Programme, the Northern States were allocated 381 (80 percent) as against $94(20 \%)$ for the Southern States. 
The Niger Delta got 63 (13.26 percent). For the Educational Rehabilitation Programme, the Northern States received 687 (71 percent) out of a total contract package of 965. The Southern States got 278 (29 percent) and the Niger Delta States got 188 (19.48 percent).

The eight years of democratic governance in the country has not changed this pattern of project allocation. For example, whereas the government has spent several billions of Naira to rehabilitate and construct new roads in the South-West and Northern parts of the country, the East-West road that links the Niger Delta with other parts of the country is neglected, and thus remains in a deplorable condition.

Political activism, spearheaded by groups such as the movement for the survival of Ogoni People (MOSOP) and the Ijaw Youth Council (IYC) among others, has made the Niger Delta people to be aware of the fact that the federal government has alienated them from the oil wealth.

This awareness cuts across the Niger Delta, and has resulted in the alienation of the people from the federal government, thus totally undermining their identification with each other. The implication is the loss of control over the people by the federal government. This has pitched the two parties against each other, leaving the oil companies as victims of the anger and frustration of the people.

The effect of this and of the alienation from the State is emerging social breakdown, as evidenced by generalised lawlessness in the Niger Delta. According to Anele (1999:171):

During periods of anomie or social breakdown, society loses its grip on the people who would wish to act according to their own dictates and not that of the collectivity. At a time like this, it is very easy to mobilize the people into mass movements because they readily make themselves available. However, mass movements, which emerge under such circumstances, do not primarily aim at changing society but to escape from their perceived isolation. From this theoretical prism, 


\section{Ibaba S. Ibaba}

people join social movements for the purpose of gaining a sense of belonging and significance, which the wider society denied them.

Youth militancy and violence, and the associated hostage taking of oil company personnel and parents of government functionaries by militia groups in the Niger Delta can be located in this context. Whereas marginalisation provided the objective condition for these groups (Adaka Marines, Movement for the Emancipation of Niger Delta, Niger Delta Peoples Volunteer Force, etc) to emerge, their pursuit of pecuniary gains explains their involvement in hostage taking for ransom - an act, which is not only out of sync with civilised practice, but also negates the Niger struggle for equity, justice and development. For many militants, the kidnapping of expatriate staff of multinational oil companies is the highest point of activism. It has become a means of livelihood and accumulation of wealth. The insecurity created by militant activities equally sustains illegal oil bunkering that costs the country four to eighteen billion US Dollars worth of oil (Vanguard 2008:1).

Despite the fact that hostage taking is seen as terrorist violence, pleas and threats by the federal government, which culminated in a presidential shoot-at-sight order in September 2006, militant activities and hostage taking have continued unabatedly. The crucial question is: Why has the Nigerian State failed to end this negative impact on the country's image, economy, and stability? The next section examines this issue.

\section{The Nigerian State and Hostage Taking in the Niger Delta}

The State, according to Harold Laski (1961:1), 'is the crowning point of the modern social edifice' and its character 'reveals it as a method of imposing principles of behaviour which regulates the lives of men'. The State 'stands for a number of particular institutions which together constitutes its reality... elements of the State include the bureaucracy, the coercive apparatus (police, army, prisons), the judiciary and the lower levels of governments' (Miliband 1969:49-54). As government 
and regime, the State is the organisational instrument of society, which provides it with the necessary cohesive factor and maintains its unity of existence (Oyovbuaire 1980:3). Political power is exercised through the State, and it is therefore the object of political competition.

The chief role of the State is the maintenance of social and political order in society. This has been a subject of debate and contention between Liberalism and Marxism. The point of argument here is on how and in whose favour the State imposes order (Ekekwe 1986:10). The liberal view is that the State is neutral in the exercise of power, and therefore, it does not promote one interest against the other. It refutes the contention of the Marxist theory that there is a ruling class that benefits more from the State. The Marxist view of the State contends that the State favours the interest of those who govern.

The Nigerian State is variously characterised as a synonym of the 'power elite', 'the Nigerian National Bourgeoisie', 'Foreign Dependent PseudoBourgeoisie with imperialism for the building of capitalism in Nigeria', 'the training of foreign and local businessmen and State officials', 'the Nigerian Bourgeoisie power and petty Bourgeoisie and the various sections', and the Nigerian capitalist class, which has developed from being a 'regional bourgeoisie into a federal bourgeoisie' (Oyovbuaire 1980:7).

The privatisation of the state defines the character of the Nigerian state. In Nigeria, politics is largely seen as a means of accumulating wealth; and because the state is the object of political competition and medium for the allocation of resources, it has been effectively used to achieve the goal of primitive accumulation of wealth. The result is the privatisation of the state by the custodians of power at all levels of governance (federal, state and local), and its consequent utilisation for the pursuit of individual, sectional and ethnic interests; as against the pursuit of the common interests or the public good (Ake 2001a; Ekekwe 1986; Nnoli 1980; Oyovbuaire 1980; Aaron 2006b). 


\section{Ibaba S. Ibaba}

The backlash is the result of the dilemma of choosing between the promotion of private or public interests. In most cases, the State promotes the private interest, and this has made it to be overtly partisan.

It is my view that hostage taking in the Niger Delta is an outcome of this crisis of identity. Hostage taking by Niger Delta militants has become a frequently occurring activity. Between January and December 2006 for instance, a total of 118 workers of different oil companies operating in the region were taken as hostages in a total of 24 attacks. Four deaths were recorded in these attacks. Similarly, a total of 129 oil workers were taken hostage in 33 attacks between January and July 2007. Again, 9 deaths were recorded. (AfricaMasterWeb 2006; Business Day 2007).

What is worrisome with hostage taking is not only the frequency, but also, the brigand and brazen manner in which it is carried out. The usual scenario is youths, sometimes masked and armed with sophisticated weapons, attacking oil company targets and engaging the military in combat. The familiar experience is the overpowering, and at times killing of security operatives. Thereafter, workers are taken captive, used as collaterals for negotiation and then released after ransom has been paid, either by government or the affected oil company.

Despite denials by the government and oil companies, it is widespread knowledge that militants receive millions of Naira as payoff in exchange for hostages in their custody. Related to this is the payment of militants to keep them out of action. For example, Asari Dokubo, the leader of the Niger Delta Peoples Volunteer Force (NDPVF), has revealed that the Rivers State Governor, at one time, was paying militants 100 million Naira to steer them away from disrupting oil production (National Standard 2007:20). This is a common practice in the Niger Delta, and partly explains the high and low tide in militancy. Militant attacks are usually low when such payments are sustained, but any breach of such compensatory payments leads to a surge in militant attacks. 
It is instructive to also note that government functionaries who are charged with the responsibility of negotiating with militants see it as a medium of making money. It is common knowledge that monies paid to militants as ransom are usually inflated. Given that hostage taking benefits some government functionaries, it is proper to argue that they cannot deal with it effectively.

Also of concern is the impunity with which the militants operate. Human Rights Watch (2005:3) has noted that:

Both the leaders of armed groups and their backers have been emboldened in their acts of brutal violence by the prevailing culture of impunity. Across the Niger Delta, as throughout Nigeria, impunity from prosecution for individuals responsible for serious human rights abuses has created a devastating cycle of increasing conflict and violence.

This probably explains the long time hostages are kept. For example, militants seized 4 expatriate oil workers on $10^{\text {th }}$ January 2006, and released them on $30^{\text {th }}$ January of same year. Similarly, 9 oil workers kidnapped on February $18^{\text {th }}$ 2006, were freed in instalments; 6 were released $1^{\text {st }}$ March, and the remaining 3, 27 $7^{\text {th }}$ March, 2006 (AfricaMasterWeb 2006). It is imperative to mention that militants dialogue/negotiate with government functionaries for days before hostages are released.

Again, another issue of concern is the fact that militant attacks are no longer limited to oil company operational sites, but now take place in the streets, offices, homes and nightclubs. Perhaps of greater concern is the attack on children. Again, militants now attack the children and parents of political office holders. Equally, the attacks impact on the country's oil production output, as production is usually disrupted. Oil companies usually shut down production as a safety measure. At times, production facilities are destroyed. For example, a militant attack on Shell Petroleum Development Company's Estuary Amatu (EA) 


\section{Ibaba S. Ibaba}

platform led to the shutdown of the facility, which regularly produces 115,000 barrels per day (Business Day 2007).

Government's dilemma in ending militant attacks is attributable to a number of factors. State legislation on the oil industry is seen as the legal and fundamental basis for the disempowerment of the Niger Delta (Nna 2001:13). For this reason, the State is seen as a party to the raging conflict, and therefore cannot mediate effectively. Because the State promotes parochial interests, it is unable to address the fundamental issues of neglect and marginalisation that have thrown up the violence.

The dominant view in the Niger Delta sees the Nigerian State and the multinational oil companies as allies in the environmental devastation of the Niger Delta. Certainly, one fact is not in doubt - that the Nigerian Government has not adequately protected the Niger Delta people. This promotes objective conditions that sustain the conflict in the region. Anikpo (1998:6) makes this point when he notes that:

Wherever the State does not provide adequate protection for individuals and communities, oil production, like all vigorous capitalist enterprises tend to deepen the matrix of social inequality and to destroy, not just the local economy or material conditions of existence but also the entire cultural cosmos within which communities define themselves, perceive their collective interests and derive their social cohesion.

It is discernible here that intra- and inter-community conflicts in the Niger Delta, induced by oil companies, is the result of the Government's failure to give the Oil Producing Communities adequate protection. Given that the inter- and intra-community conflicts provide a breeding ground or nursery for the recruitment of militants, the Nigerian State appears to have shot itself in the leg by neglecting the Niger Delta.

The privatisation of the State makes it corrupt, and as noted earlier, this alienates citizens from the State. This makes the State to lose control of 
citizens who do not see themselves as stakeholders in the Nigerian project. Certainly, the State's ability to resolve the conflict is severely limited. A consequence of privatisation of the State is the desperate struggle for power, and the resultant election rigging, thuggery and violence.

The desperate struggle for power by politicians has helped to lay and strengthen the foundations of militant activities in the Niger Delta. During elections, politicians engage youths as political thugs to secure victory. From all indications, this support is the basis of militant groupings. Significantly, the actions of the youth/militant groups usually spin out of control. Human Rights Watch (2005) partly blamed this for the internecine violence that engulfed Rivers State in 2004. Also writing on the Rivers State experience in 2003, Joab-Peterside (2005:46-47) noted that:

Idle youths that operate as political thugs and militia groups were recruited because of their fire-powers and paid heavily for services, thereby transforming violence into a commodity priced and purchased in the democratic process... The involvement of the armed groups in the democratic process catapulted their leaders and members to positions of political prominence.

This is a graphic illustration of what is obtainable in the other Niger Delta States, and provides an explanation for the inability of these governments to deal with the militants.

Essentially, democracy as a system of government that places ultimate authority of government in the people, so that public policy is made to conform to the will and interests of the people (Gauba 2003:421), is predicated on elections. It is imperative to highlight that the conduct of free and fair elections is the fundamental basis of democratic governance. Through elections, citizens choose leaders to direct the affairs of government for the benefit of all. 


\section{Ibaba S. Ibaba}

When elections are rigged, the freedom and right to choose leaders is denied, and this has several implications. When people vote at elections to form a government, a contract is established. The government is created for a purpose (the well being of the people) and is therefore bound by the contract to fulfil its side of the bargain. Significantly, if the leadership of a government is not chosen by the people, the government is not bound by any contract, thus it tends to be unresponsive to the needs of the people. The instrument of recall and impeachment, which acts as a check on the excesses and inefficiency of elected representatives and government functionaries has become impotent. This perverts the end of government, and consequently, the aspirations of citizens are hardly met.

Also election rigging creates problems of legitimacy. When a government is seen to be illegitimate, it undermines the identification between the people and the government; the citizens tend to become disobedient and refuse to cooperate with it. This weakens the efficiency of the government as it creates a crisis of authority (Ake 2001b:34), and a tendency to become authoritarian, as shown by State response to agitations in the Niger Delta. Leaders who emerge from rigged elections lack credibility, and this is seen as a major cause of conflict in the Niger Delta (Peel 2005:3). Because such leaders lack credibility, they do not command respect, and thus find it difficult to elicit obedience.

A logical outcome of election fraud is the lack of accountability in governance, fuelled by the drive of government functionaries to recoup the monies 'invested' in the elections. Accordingly, State resources are appropriated for personal gain. The implication here is that the monies that ought to be invested in national development are diverted, through inflation of contracts, payment for 'ghost' projects, etc.

Given this, the expected development, which should accompany democracy, is not forthcoming. The inability of the government to promote development worsens poverty and hardship, which aggravates the anger 
of those who feel cheated at the elections. This pent up anger creates a fertile ground for instability as little disagreements easily turn to violence.

The inability of government to promote development is one of the major causes of its inability to tackle militancy in the Niger Delta. To be sure, the low level of infrastructural development limits the effectiveness of security operatives. The absence of a network of roads and canals for easy communication enhances the activities of militants who exploit the advantages of difficult communication to carry out their activities.

Poverty and unemployment have made many youths to be vulnerable to militant mobilisation. For many of the youths, militancy and hostage taking is a means of livelihood and a demonstrative effect of corruption and conspicuous consumption among government functionaries. To end this means providing viable alternative means of livelihood for those who will come out of it. It equally requires an end to corruption in government. Threats, appeals and dialogue will not end it. What government ought to do is to invest in the people as a strategy of development. However, the culture of politics, which directs public resources to the benefit of individuals and groups, negates this.

It is useful to note that violence was used as an instrument of rigging in the 2007 general elections. Guns, dynamite and other dangerous weapons were used to scare away political opponents, and intimidate election officials. The consequence of this was the empowerment of youths who are active militants and have a tendency to legitimise violence. Again, the nature of the 2007 general elections has created and deepened apathy towards the business of government, as many Nigerians do not see themselves as stakeholders. The emerging consensus among a generality of the citizens is that democracy is meant for a powerful few, who take all they see and get all they want; in what is widely known as 'carry go'. This constrains meaningful popular participation in politics and government (Nwabueze 1993:2), a fundamental requirement for democratisation. 
A major outcome of this, is the loss of faith in democratic institutions and the emergence of a parochial political attitude. It is significant to note that the executive is not trusted and thus not seen to be dependable or reliable; the legislature is seen as a stooge of the executive and therefore not useful to deal with; and the judiciary is held with contempt. This provides an explanation for the restiveness in the creeks of the Niger Delta.

A seemingly neglected factor of alienation in the Niger Delta is corruption, as transparency and accountability failures have deepened neglect and exclusion that explains militancy and violence in the region. Whereas the oil companies and the federal government are guilty of corruption, the paper highlights the corruption of States and local governments of the Niger Delta. This theme appears neglected, and robs us of a holistic view of the Niger Delta condition.

The implementation of the 13 percent derivation principle in 2000, led to a significant increase in the funds allocated to the Niger Delta States. For example, the figures for March 2005, show that Rivers State received N8.6 billion, Bayelsa State N9.3 billion, and Delta State N6.3 billion. In contrast, Lagos State, the most populous in the country received N2.5 billion (Peel 2005:4). Available data reveal the huge funds that have flowed into the region since 2000. See table 2, below.

Table 2: Allocation of 13\% Derivation Fund to Niger Delta States, 2000-2003 (=N=Billion)

\begin{tabular}{|c|l|l|l|l|l|}
\hline $\begin{array}{c}\text { Serial } \\
\text { No }\end{array}$ & \multicolumn{1}{|c|}{ State } & Year 2000 & Year 2001 & Year 2002 & Year 2003 \\
\hline 1 & Akwa Ibom & $12,808.2$ & $16,717.1$ & $7,068.7$ & $16,094.9$ \\
\hline 2 & Bayelsa & $10,571.2$ & $13,797.4$ & $17,485.8$ & $22,726.4$ \\
\hline 3 & Cross River & 1,2 & 1,6 & $8,836.0$ & $1,768.0$ \\
\hline 4 & Delta & $17,433.7$ & $22,754.9$ & $30,427.5$ & $33,672.7$ \\
\hline 5 & Edo & 337,1 & 439,8 & 6,737 & $1,236.0$ \\
\hline 6 & Rivers & $10,571.2$ & $13,797.6$ & $23,106.6$ & $25,854.7$ \\
\hline
\end{tabular}

Source: African Network for Environment and Economic Justice (ANEEJ) 2004:73-76. 
It is expected that these monies will be invested in the development of the region, to the extent that the fruits will not be in doubt. However, this is not the case, as poverty, unemployment and absence of basic social amenities are conspicuous. Paradoxically, political leaders of the region live in affluence, as they divert public funds to the promotion of their parochial and selfish interests. For example, revelation by the Economic and Financial Crimes Commission (EFCC) shows that governors of the Niger Delta States have stolen billions of Naira from their State treasuries. This reality has made many of the youths lose faith in the leaders who have lost credibility. The implication of corruption is the exacerbation of the material deprivations that have thrown up the conflicts and violence and the resultant militancy. Because the investment of resources in the people comes into conflict with the selfish interests of the leaders they choose to neglect the people, and thereby sustain militancy.

\section{Conclusion}

Following years of neglect and marginalisation by the federal government, corruption at all levels of the Nigerian State (federal, state and local government), and ecological devastation by oil exploration and production activities of multinational oil companies, the Niger Delta is extremely poor, despite its huge oil wealth. This grim reality has provided a fertile ground for conflicts to erupt. Protest and agitations by communities, demanding adequate share of the oil wealth and environmental protection, have led to the emergence of militant groups that have adopted hostage taking as strategy of protests.

Militants seize oil workers, keep them for extensive periods and use them as collateral for negotiation. The desperation by government and the oil companies to secure kidnapped staff, usually expatriates, has turned hostage taking to a means of livelihood and medium for the accumulation of wealth. Despite the destructive impact of this on the economy 


\section{Ibaba S. Ibaba}

and image of the country, threats and militarisation of the Niger Delta, the phenomenon remains unabated.

The use of the state, a public institution, for the pursuit of personal, sectional, and ethnic interests, has undermined the capacity of the state to deal with militancy and hostage taking by militants. To deal with this issue, the custodians of state power at all levels (federal, state and local government) will need to commit symbolic suicide (Wilmot 1982:148) by subordinating their personal, sectional and ethnic interests to the common interests or public good. However, they are reluctant to do this. Meanwhile, the privatisation of the state has created a situation where the institutions of oil wealth distribution (bureaucracies of the federal, state and local governments) are so corrupt that only an infinitesimal proportion of budgeted funds trickle down to the Oil Producing Communities. Thus, the development problems of the people remain unresolved, and this sustains the objective conditions that have instigated militancy.

Elections, the central element of democracy are abused through rigging. The result is transparency and accountability failures, loss of faith in democratic institutions and the exacerbation of the problems of underdevelopment - poverty, unemployment, lack of social amenities, etc. The implication of this is the alienation of citizens from the State, social breakdown, and the loss of control by the State. Here lies the dilemma of the Nigerian State in dealing with the menace of hostage taking.

Hostage taking of oil workers has become a lucrative business that appears difficult to deal with. To end it requires the provision of alternative and viable means of livelihood to the militants. Also, the objective conditions that have brought on conflicts and violence in the Niger Delta need to be liquidated, and adherence to the ideals of transparency and accountability in governance have to be established. It is clear that the present nature of the Nigerian State makes this a tall order. The solution lies with the transformation of the State, to purge it of its ethnic character and pursuit of parochial interests. This requires that those who 
lead must subordinate their personal interest to the common or public good. Non-state actors can advance this goal by mobilising the citizens to demand accountability and transparency in governance.

\section{Sources}

Aaron, K.K. 2006a. Human Rights Violation and Environmental Degradation in the Niger Delta, in Porter, Elizabeth \& Offord, Baden (eds), Activating Human Rights. New York: Peter Long, Oxford Borne.

Aaron, K.K. 2006b. Can a Privatized State Privatize? Insights and Experiences from Nigeria's Privatization Programme. THEDI Monograph No.1. Port Harcourt: Kemuela Publications.

Adeyemo, A.M. 2002. The Oil Industry, Extra-Ministerial Institutions and Sustainable Agricultural Development: A Case Study of Okrika LGA in Rivers State. Nigerian Journal of Oil and Politics 2 (1), 60-78.

AfricaMasterWeb 2006. <http://www.africamasterweb.com/Adsense/Nigerianmilitants06chronology.html>. Accessed December 2006.

African Network for Environment and Economic Justice (ANEEJ) 2004. Oil of Poverty in Niger Delta. Lagos: ANEEJ.

Ake, Claude 2001a. The Political Question, in Alapiki, H.E. (ed), The Nigerian Political Process. Port Harcourt: Emhai Printing and Publishing Company.

Ake, Claude 2001b. The State in Contemporary Africa, in Alapiki, H.E. (ed), The Nigerian Political Process. Port Harcourt: Emhai Printing and Publishing Company.

Aklaka Declaration 1999. Resolutions of the Egi Ethnic Coalitions at the end of a conference on $10^{\text {th }}$ January, 1999.

Anele, K.A. 1999. Social Change and Social Problems in Nigeria. Owerri: Springfield Publishers.

Anikpo, Mark 1998. Communal Conflict in the East Niger Delta: A Cultural Matrix. Pan African Social Science Review 3, 1-12.

Bill of Rights of the Oron People 1999. Resolutions of the Oron people, June 25, 1999.

Brown, Bobo 1998. External Relations manager of the Shell Petroleum Development Company (SPDC) of Nigeria, quoted in Environment Watch, 15 July 1998, 3-9.

Business Day 2007. July 26, 2007.

Clark, Henry; Green, Elwyn; Liuti, Laura; Turner, Walter; Quarto, Alfredo; Richard, Margie; Tate, Umar; Wilson, Monica and Wyshan, Daphne 1999. Oil for Nothing: Multinational Corporations, Environmental Destruction, Death and Impunity in the Niger Delta, A United States Non-Governmental Delegation Trip Report, 1999.

Ekekwe, E. 1986. Class and State in Nigeria. Lagos: Macmillan, Nigeria.

Environment Watch 1998. July 1998. 


\section{Ibaba S. Ibaba}

Enyia, N.T. 1991. Oil Exploration and Production in Rivers State: An Analysis of the Political and Socio-Economic Consequences for Six (6) Communities: 1950-1990. $\mathrm{PhD}$ Dissertation, Department of Political/Administrative Studies, University of Port Harcourt, Nigeria.

Faleti, Stephen Ademola. No date. Theories of Social Conflict, in Gayo, Best Shedrack, Introduction to Peace and Conflict Studies in West Africa, Ibadan: Spectrum Books Limited.

Frederick, A.O. 2008. A Theoretical Consideration of the Niger Delta Crisis: Whose Solution? The People's or the Government's? Paper presented at the International Conference on the Nigerian State, Oil Industry and the Niger Delta, Yenagoa, Bayelsa State, Nigeria, March 11-13 2008.

Gauba, O.P. 2003. An Introduction to Political Theory. $4^{\text {th }}$ edition. Delhi, India: Macmillan, India Limited.

Human Rights Watch 1999. The Price of Oil. Available at <http://www.hrw.org/ reports/1999/Nigeria/Nigew991-01.htm>.

Human Rights Watch 2005. Rivers and Blood: Guns, Oil and Power in Nigeria's Rivers State. Briefing Paper, February, 2005.

Ibaba, Ibaba S. 2005. Understanding the Niger Delta Crisis. Port Harcourt: Amethyst and Colleagues Publishers.

Ibeanu, O. 1997. Oil Conflict and Security in Rural Nigeria: Issues in Ogoni Crisis. African Association of Political Science, Occasional Paper Series 1, Harare, 1997.

Ikein, A.A. 1991. The Impact of Oil on a Developing Country: The Case of Nigeria. Ibadan: Evans Brothers (Nigeria Publishers) Limited.

Ikporukpo, C.O. 2004. Petroleum, Fiscal Federalism and Environmental Justice. Space and Polity 18 (3), 321-354.

Joab-Peterside, S. 2005. On the Militarisation of Nigeria's Niger Delta: The Genesis of Ethnic Militia in Rivers State. African Conflict Profile 1(2), 30-29.

Kaiama Declaration 1998. Resolutions of the December $11^{\text {th }}$ All Ijaw Youths Conference, Kaiama, Bayelsa State, 1998.

Laski, Harold 1961. Introduction to Politics, London: George Allen \& Unwin Publishers.

Mbanefoh, G.F. \& Egwaikhide, F.O. 1998. Revenue Allocation in Nigeria: Derivation Principle Revisited, in Amuwo, Kunle et al (eds), Federalism and Political Restructuring in Nigeria. Ibadan: Spectrum Books Limited.

Miliband, Ralph 1969. The State in Capitalist Society, London: Weidenfeld \& Nicolson.

Naanen, Ben 1995. Oil Producing Minorities and the Restructuring of Nigerian Federalism. Journal of Common Wealth and Comparative Politics 33 (1), 46-78.

National Standard 2007. November 15, 2007.

Niger Delta Environmental Survey 1995. Briefing Note, October 1995

Nna, N.J. 2001. The Niger Delta: State Legislation and Disempowerment, Owerri: Springfield Publishers. 


\section{Alienation and Militancy in the Niger Delta}

Nnoli, O. 1980. Ethnic Politics in Nigeria, Enugu, Fourth Dimension Publishers.

Nwabueze, B.O. 1993. Democratization, Ibadan: Spectrum Law Publishing.

Ogoni Bill of Rights 1990. Adopted by General Acclamation of the Ogoni people.

Okoko, Kimse 1998. The Shell Petroleum Development Company (SPDC) - Host Community Relations Survey. A report submitted to SPDC Western Operations, Warri, Nigeria.

Okoko, Kimse \& Nna, N.J. 1997. Federalism and Resource Allocation: The Nigerian Experience. Nigerian Journal of Oil and Politics 1 (1), 16-35.

Okoko, Kimse \& Nna, Johnson 1998. Revenue Allocation and the Oil Producing States in Nigeria, in Alapiki, Henry (ed), Perspectives on Socio-Political and Economic Development in Nigeria. Owerri: Springfield Publishers.

Okorede, V.E.A. 1998. Perceived Security Environment of Nigerian Nation. Journal of Nigerian Affairs 3 (1), 18-29.

Opukri, C.O. \& Ibaba, S.I. 2007. Oil Based Environmental Degradation and Internal Population Displacement in the Niger Delta. Paper presented at the second National Conference of the faculty of Business and Social Sciences, University of Ilorin, Ilorin, Nigeria, February 27-28, 2007.

Orobator, Ekele et al 2005. Federal State and Resource Control in Nigeria. Benin: F. Parker Publishing Company.

Owugah, Lemmy 1999. Local Resistance and the State. Paper presented at Oil Watch African General Assembly, Port Harcourt, February 9-14, 1999.

Oyovbuaire, S. 1980. The Nigerian State as a Conceptual Variable, in Edogun, Cliff (ed), Nigeria: Politics, Administration and Development. Port Harcourt: The Nigeria Political Science Association, University of Port Harcourt, Nigeria.

Peel, Michael 2005. Crisis in the Niger Delta: How Failures of Transparency and Accountability are Destroying the Region. Briefing Paper, Chatham House African Programme, July, 2005.

Resolutions of the First Urhobo Economic Summit 1998. Organised by Urhobo Foundation, Effurun, Warri, Delta State, November 27-28, 1998.

Salau, A.T. 1993. Environmental Crisis and Development in Nigeria. Inaugural Lecture, University of Port Harcourt, Nigeria.

Tamuno, Tekena 2000. The Niger Delta Question. Port Harcourt: Riverside Communications.

TELL Magazine 1999. No.36, September 6, 1999.

The Constitution of the Federal Republic of Nigeria 1960. Lagos: Ministry of Information.

The Constitution of the Federal Republic of Nigeria 1963. Lagos: Ministry of Information.

United Nations Development Programme (UNDP) 2006. Niger Delta Human Development Report. Lagos: UNDP. 
Vanguard 2008. July 4.

Warri Accord 1999. Warri Declaration Adopted after Deliberations at the Warri Families at the Warri National Conference, Benin, June 25-27, 1999.

Willinks Commission Report 1957. Report of the Commission appointed to Enquire into the Fears of Minorities and the Means of Allaying them. London: Her Majesty's Stationery Office.

Wilmot, F. Patrick 1982. Apartheid and African Liberation. Ile Ife: University of Ife Press.

Worika, I.L. 2002. Environmental Law and Policy of Petroleum Development: Strategies and Mechanisms for Sustainable Management in Africa. Port Harcourt: Anpez Centre for Environment and Development.

World Bank Report 1995. Defining an Environmental Development Strategy for the Niger Delta. Vol. One, 1995. 